only identifying weaknesses, but 'constituting at least for the time the audience's sense of the power relations between the privileged and powerless, whether socially, financially, or in terms of gender'. This collection provides an interesting intervention in the continuing debates about this particular period of theatre history, inviting the reader to consider the wide range of political commentary that analysis of the Stuart theatre provides.

SOPHIE NIELD

John Henry Jones, ed.

The English Faust Book

Cambridge University Press. 1994. £50.00, \$80 00. ISBN 0-521-42087.

The history of the early printed editions of both the German and the English Faust Book is complicated. Dr. Jones, a leading expert in the Faust legend, offers a chronology, together with a complete transcription of the 1592 Orwin edition of the English Faust Book and a tentative identification of its author as $P$. F. Gent. The transcription is printed in such a way as to highlight $P . F$. Gent's translation of, omissions, alterations and additions to the text of the German Faust Book (which makes for interesting reading), together with full commentary and bibliographical notes.

This eminently scholarly book throws light not only on Marlowe's Dr. Faustus but also on the 'conjuring tricks' of Friar Bacon and Friar Bungay in Greene's play and those of Prospero in Shakespeare's The Tempest. What emerges is that the English Faust Book is more than a mere translation of the German: rather, it is a pro-Christian moral document together with a rather confused account of the creation theory of the universe (P. F. Gent's additions to the original German text indicate his belief in a heliocentric universe but still with the idea of fixed heavenly spheres). Thus, by inference, Dr. Jones's book quite clearly shows how Marlowe's play walked the tightrope of both contemporary orthodox Christianity and accepted creation theory.

P. S. COOK

John Russell Stephens

The Profession of the Playwright:

British Theatre, 1800-1900

Cambridge University Press, 1992. 254 p. $£ 40.00$. ISBN 0-521-25913-4.

The last few years have seen a further dimension to study of the Victorian theatre. Added to genre description and analysis of stage performance is awareness of the transformation of the theatre from a cottage craft to a full-scale industrial process. One of the more useful additions to this area of research is John Russell Stephens's analysis of the dramatist's profession, in which he charts the playwright's increasing freedom to market his (no female dramatists are discussed) wares and growing financial independence as he progresses from a tied-to-a-playhouse servant to a free agent whose name is recognized by audiences and whose works are sought by managers.

Stephens is chiefly concerned with such recognition and remuneration, as betokened by published texts and the doubtful flattery of pirated editions, longer runs, a share of the profits, respectability, and honours. That is his strength, and with convincing research he brings the profession from obscurity to adulation. He is less successful in describing how these playwrights worked and, in particular, in noting and analyzing discernible changes in working practices.

It might have been helpful, for example, to enquire why, in the latter three decades of the nineteenth century and in the first two of the present, so many British playwrights (such as Herman and Jones, Raleigh and Hamilton, Sims and Pettitt, Sims and Buchanan) worked in pairs. There is more than a little evidence to hand to suggest that these writers' teams were actually industrializing the process of writing, creating an assembly line with each team member applying his special knack to the written product - a product efficiently entertaining, efficiently utilizing largely predictable acting skills, appropriately provocative, sensational as required, remountable for touring productions, distinctive and recognizable to their public, remunerative to managements, but with scant claim to literary merit.

Perhaps that is another dilemma for Stephens. The playwrights who ultimately interest him are those who are today acknowledged as significant dramatists and for whose work he can claim even modest literary merit. Mere popular success does not qualify. Thus Tom Robertson, Bernard Shaw, and Arthur Pinero matter; Wilson Barrett, author of the single most popular play of the last century, does not, and is too easily dismissed as a writer of 'cheap and sentimental pieces'. Despite these cavils, Stephens's book deserves to be read with scholarly gratitude.

DAVID MAYER

\section{F. W. J. Hemmings \\ Theatre and State in France, 1760-1905 \\ Cambridge University Press, 1994. 285p. £37.50. ISBN 0-521-45088-8.}

In this second book, which complements his earlier The Theatre Industry in Nineteenth-Century France, Hemmings again offers an impressive and wide-ranging study which details how the material conditions of theatre are affected by state control and intervention. In a style which is 
both readable and scholarly, the study includes documentation of the working conditions of performers (with illuminating detail on the imprisonment of actors and actresses); theatres, plays, and performances during the French Revolution; the declining prosperity of provincial theatre in relation to the political and cultural hegemony of Paris; the licensing system (which, until its abolition in 1864, prevented women from managing theatres); the 'guerilla tactics' of audiences in subversive, political applications to the meanings of productions; the Parisian institution of the café-concert; and the role of dramatic censorship until its abolition in 1905.

The tensions between state and theatre make this volume of interest to students of French theatre, history, and culture. The final chapter on 'the private sector', which looks out to the unofficial margins of the theatre industry (from the theatrical enterprises of Marie-Antoinette to the private performances of André Antoine), contains the germ of a future full-length study - the next Hemmings volume?

ELAINE ASTON

\section{Katherine K. Preston}

Opera on the Road: Travelling Opera Troupes in the United States, 1825-60

Urbana; Chicago: University of Illinois Press, 1993. 479 p. $\$ 39.95$.

ISBN 0-252-01974-1.

Opera scholarship (at least, in the hands of British and American historians) has traditionally restricted itself to examining opera within the confines of the major opera houses, thus encouraging the notion that this particular art form was an exclusive entertainment designed primarily for the social elite and performed by a handful of international stars. Katherine K. Preston's study offers a refreshingly different perspective.

By investigating the many itinerant companies that traversed the Americas, led by impresarios such as Max Maretzek or singers such as Jane Shirreff and John Wilson, Preston demonstrates that opera was attended and enjoyed by a broad base of social classes in a surprisingly wide variety of venues during the antebellum period. She also reveals that operatic performers ranged from established singers to stock company actors who played supporting roles in operatic productions.

Her methodology is essentially that of the theatre historian rather than the musicologist, and her placing of opera in its theatrical context reaps such benefits as a discussion of the popularity of operatic burlesques. There is little description of actual performances or mise en scène, but otherwise Preston's meticulous research provides a thorough account of vocal-star, Italian, and English opera companies that will be of inestimable aid to other scholars. Extensive appendices detail the personnel of various opera companies and the venues that they played.

SUSAN RUTHERFORD

\section{Twentieth-Century Theatre}

Anton Kaes, Martin Jay, Edward Dimendberg, eds.

The Weimar Republic Sourcebook

Berkeley: University of California Press, 1994.

806p. $£ 45.00$

ISBN 0-520-06774-6.

This extensive compilation offers original texts following thirty differing chronological approaches to this diverse and problematic period of German history. These address not only politics and culture, but also sexuality, advertising, sport, and the rise of the new woman. The 327 passages selected present a kaleidoscope of brief glimpses (few of more than two sides) from the most disparate of sources.

Most if not all of the leading historical figures are represented, but equally fascinating are the comments of relatively obscure individuals. These together succeed in presenting a remarkably balanced, rounded, and convincing picture of a society attempting to define itself in a world in which the traditional certainties seemed devoid of any validity. Its wide scope should ensure that the volume is of interest to scholars from many fields, including theatre, as well as being invaluable to the student in search of the authentic flavour of life in Germany during this crucial period.

ANTHONY MEECH

John Pilling, ed.

The Cambridge Companion to Beckett

Cambridge University Press, 1994. 249 p.

$£ 35.00$ (hbk), $£ 11.95$ (pbk).

ISBN 0-521-41366-4 (hbk), 0-521-42413-5 (pbk).

This volume of thirteen essays on Beckett is organized both chronologically and by genre. An initial essay on Beckett's critical writings is followed by two devoted respectively to his English fiction and the three French novels and four nouvelles of the late 1940s and early 1950s, with a further five items on his theatre, from Waiting for Godot to the later Dramaticules. These are complemented by contributions on the late prose pieces and a number of more general essays on his poetry and verse translations, his work as a stage director, his relationship to 'the philosophers', and, finally, the crucial issue of his bilingualism ('Heavenly father, the creature is bilingual!', as Beckett's first published protagonist 